\title{
TANGGUNG JAWAB PENGELOLA PASAR ATAS PENJUALAN HASIL PRODUK YANG MELANGGAR HAK CIPTA
}

\author{
Oleh: \\ Ida Ayu Agung Nara Kirana Udiyana** \\ I Gusti Ngurah Parwata*** \\ Program Kekhususan Hukum Bisnis \\ Fakultas Hukum, Universitas Udayana
}

\begin{abstract}
ABSTRAK
Pelaksanaan aktifitas dagang merupakan sebuah upaya pemenuhan kebutuhan hidup seorang manusia. Aktifitas dagang tersebut melibatkan beberapa tokoh yakni konsumen, penyalur, produsen. Aktifitas dagang juga dapat dimanifestasikan melalui pelaksanaan kerjasama antara pengelola pasar melalui kerjasama dalam bentuk perjanjian konsinyasi atas penjualan produk yang melanggar hak cipta melalui adanya penggandaan barang. Dalam jurnal ini terdapat pemasalahan pertama yang membahas tentang bagaimana pengaturan dan bentuk perbuatan pelanggaran hak cipta; serta permasalahan kedua membahas pada bentuk pertanggungjawaban yang seharusnya diberikan oleh pengelola pasar yang menjual hasil barang pelanggaran hak cipta. Adapun tujuan dari tulisan ini untuk memahami pelaksanaan dari bentuk pengaturan maupun tanggung jawab yang berkaitan dengan penjualan produk yang melanggar hak cipta. Metode yang digunakan adalah metode penelitian hukum normatif dengan pendekatan analisis dan konseptual, perundang-undangan dan kasus. Hasil akhir dari penyusunan jurnal ini menunjukan adanya pengaturan dan bentuk perbuatan pelanggaran hak cipta terkait pelaksanaan konsinyasi; serta bentuk pertanggungjawaban yang sepatutnya diberikan oleh salah satu pihak pengelola pasar yang menjual hasil barang pelanggaran hak cipta.
\end{abstract}

Kata Kunci: Konsinyasi, Hak Cipta, Pengelola Pasar, Pelanggaran

${ }^{*}$ Artikel ini bukan merupakan hasil ringkasan skripsi.

** Ida Ayu Agung Nara Kirana Udiyana (1604551165) adalah Mahasiswa Program Kekhususan Hukum Bisnis, Fakultas Hukum Universitas Udayana, Korespondensi melalui email 9fdayunara19@gmail.com. Udayana.

${ }_{* * *}^{*}$ I Gusti Ngurah Parwata adalah dosen Fakultas Hukum Universitas 


\begin{abstract}
The implementation of trade activities is an effort to fulfill the needs of a human life. These trade activities involve several figures namely consumers, suppliers, producers. Trade activities can also be manifested through the implementation of cooperation between market managers through collaboration in the form of consignment agreements on the sale of products that violate copyright through the multiplication of goods. In this journal there is the first issue that addresses how the arrangement and form of copyright infringement acts; and the second issue addresses the form of accountability that should be given by market managers who sell the products of copyright infringement. The purpose of this paper is to understand the implementation of the form of arrangements and responsibilities relating to the sale of products that violate copyright. The method used is a normative legal research method with an analytical and conceptual approach, legislation and cases. The final results of the preparation of this journal indicate the existence of arrangements and forms of copyright infringement related to the implementation of consignment; and forms of accountability that should be given by one of the market managers who sell the products of copyright infringement.
\end{abstract}

\title{
Keywords: Consignment, Copyright, Market Managers, Violations
}

\section{PENDAHULUAN}

\subsection{Latar Belakang}

Metode perdagangan merupakan sebuah alternatif yang digunakan oleh beberapa kelompok masyarakat untuk meningkatkan partisipasi pembeli pada produk yang dihasilkannya sendiri. Laba merupakan sebuah orientasi utama dari perdagangan sehingga peminatan terhadap sebuah aktifitas yang menghasilkan keuntungan tinggi akan menjadi tautan utama dari para pedagang. Di dalam aktivitas dagang terdapat produsen sebagai pihak yang melakukan kegiatan produksi untuk menghasilkan produk berupa barang atau jasa; distributor sebagai pihak yang melakukan distribusi yaitu dengan mengantarkan produk berupa jarang dan jasa dari produsen ke konsumen; konsumen sebagai pihak yang melakukan kegiatan dalam menggunakan atau menghabiskan nilai 
produk berupa barang atau jasa. Di dalam perdagangan, pasar dalam arti "tempat" sebagai sebuah tempat untuk bertemunya antara pedagang dan pembeli, dalam arti "penawaran dan permintaan" pasar sebagai tempat melakukan transaksi jual beli barang atau jasa, pasar dalam arti "sekumpulan orang yang mempunyai kebutuhan serta daya beli" merupakan masyarakat yang berusaha untuk mendapatkan barang atau jasa serta mempunyai kemampuan untuk membeli barang tersebut. Selain itu pasar juga memiliki fungsi untuk memudahkan pedagang untuk menjual dan memperkenalkan barangnya terhadap konsumen. Namun dalam aktivitas pasar, terdapat banyak pengelola pasar menjual barang-barang yang melanggar hak cipta. Kegiatan tersebut dilakukan oleh pengelola pasar ketika barang yang ia jualkan berasal dari penggandaan suatu barang yang dihasilkan oleh pencipta sebelumnya. Penggandaan suatu barang bertujuan untuk memperbanyak penjualan suatu barang yang mereka beranggapan bahwa barang tersebut sudah memenuhi keinginan masyarakat, sehingga barang tersebut dapat terjual dengan mudah dan akhirnya mendapat laba yang besar.

Tempat menjual barang-barang pelanggaran hak cipta dapat dilakukan di pasar tradisional, pasar modern maupun usaha milik sendiri dengan cara konsinyasi (menitipkan barang) yang faktanya pelaksanaan konsinyasi sendiri dinilai sebagai bentuk dari perjanjian yang tidak bernama namun memiliki tujuan yang pasti mendapatkan laba atas penjualan produk. ${ }^{1}$ Kaitannya dengan pelanggaran hak cipta, saat adanya konsinyasi antara pihak yang menitipkan barang dengan yang menjualkan barang sudah melakukan perjanjian, tetapi adanya pelanggaran atas karya cipta h. 63.

${ }^{1}$ Faisal, 2015, Pemaknaan Hukum Progresif, Thafamedia Press, Semarang, 
berupa penggandaan atau memperbanyak produk yang dikomersilkan tanpa ijin si pencipta. Sehingga si pencipta tidak mendapatkan hak nilai ekonominya yang menyebabkan si pencipta tidak dapat memperoleh keuntungan materi padahal ia yang sudah bersusah payah dalam membuat dan memperkenalkan barang tersebut.

Pelanggaran hak cipta tersebut tidak hanya berlaku bagi pihak yang menjualkan barang, tetapi juga orang yang menyediakan tempat untuk menitipkan barang tersebut pun harus dipertanggungjawabkan. Oleh karena itu perlunya perlindungan hukum mengenai pelanggaran hak cipta, sehingga hak cipta tersebut dapat dijaga keasliannya dan tidak digunakan secara sembarangan oleh oknum-oknum yang tidak bertanggung jawab; serta perlu adanya suatu pertanggungjawaban yang dilakukan oleh pelaku pelanggar hak cipta apabila terjadinya pelanggaran atas karya cipta di tempat perdagangannya. Dengan demikian pengaturan Hak Cipta di Indonesia dapat terlaksana dengan baik, meskipun perlu adanya kesadaran sendiri dari pelaku pelanggar hak cipta untuk tidak lagi melakukan hal-hal yang melanggar hak cipta. Didasarkan oleh pertimbangan tersebut, maka disusunlah jurnal berjudul "Tanggung Jawab Pengelola Pasar Atas Penjualan Hasil Produk Yang Melanggar Hak Cipta".

\subsection{Rumusan Masalah}

1. Bagaimana pengaturan dan bentuk perbuatan pelanggaran hak cipta?

2. Bagaimana bentuk pertanggungjawaban yang seharusnya diberikan oleh pengelola pasar yang menjual hasil barang pelanggaran hak cipta?

\subsection{Tujuan Penulisan}


1. Untuk mendeskripsikan pengaturan terkait hak cipta dan bentuk perbuatan pelanggaran hak cipta yang terjadi dalam pengelolaan pasar.

2. Untuk mengetahui bentuk pertanggungjawaban oleh pengelola pasar apabila terjadinya penjualan hasil barang pelanggaran hak cipta.

\section{ISI MAKALAH}

\subsection{Metode Penelitian}

Metode yang digunakan dalam penelitian ini adalah jenis penelitian normatif didukung oleh pendekatan perundangundangan, pendekatan kasus dan pendekatan analisis dan konseptual. Penelitian ini bersifat monodisipliner dengan menjadikan ilmu hukum sebagai tautan utama penelitian. ${ }^{2}$ Penelitian ini menggunakan bahan hukum primer berupa peraturan perundang-undangan, bahan hukum sekunder terkait literaturliteratur serupa ataupun bacaan yang berasal dari karya tulis ilmiah lain. ${ }^{3}$ Ruang lingkup rumusan masalah pertama dibatasi pada aspek peraturan perundang-undangan yang mewadahi pengaturan mengenai penjualan hasil barang pelanggaran hak cipta; sedangkan rumusan masalah kedua dibatasi pada aspek bentuk pertanggungjawaban dalam aktivitas pasar terkait penjualan hasil barang yang melanggar hak cipta.

\subsection{Hasil dan Pembahasan}

\subsubsection{Pengaturan dan Bentuk Perbuatan Pelanggaran Hak Cipta}

Hak cipta didefinisikan dalam Pasal 1 angka 1 Undang-Undang Nomor 28 Tahun 2014 Tentang Hak Cipta sebagai hak eksklusif pencipta yang timbul secara otomatis berdasarkan prinsip

2 Diyah Octorina Susanti dan A'an Effendi, 2010, Penelitian Hukum, Sinar Grafika, Surabaya, h. 20.

${ }^{3}$ Ibid, h. 110. 
deklaratif setelah suatu ciptaan diwujudkan dalam bentuk nyata tanpa mengurangi pembatasan sesuai dengan ketentuann peraturan perundang-undangan. Hak Cipta yang dimaksudkan sebagai hak eksklusif ketika si pencipta atau pemegang hak cipta memiki wewenang dalam mengatur penggunaan hasil karya yang berarti hak tersebut melekat erat kepada pengelolanya yang merupakan kekuasaan pribadi atas ciptaan yang bersangkutan. Oleh sebab itu, maka tidak ada satupun pihak lain yang dapat memanfaatkan hak cipta kecuali atas izin si pencipta. Hal tersebut dilatar belakangi dengan adanya pemikiran bahwa dalam menciptkan suatu karya cipta adalah hal yang tidak mudah. Menciptakan sesuatu harus didasari dengan kreatifitas dan diawali dengan mencari inspirasi terlebih dahulu sehingga menghasilkan sebuah pemikiran untuk mewujudkan ciptaan. Dengan hak eksklusif yang dimiliki oleh pencipta, maka orang lain tidak boleh meniru atau menjiplak atau menggandakan ciptaan tersebut secara sembarangan karena dapat menimbulkan pelanggaran hak cipta. Jika suatu karya cipta dirancang oleh seseorang namun diwujudkan dan dikerjakan oleh orang lain, tetapi masih di bawah pimpinan dan pengawasan perancangnya, maka yang dianggap sebagai penciptanya adalah orang yang merancang atas ciptaan itu. ${ }^{4}$ Dalam konteks ini hak cipta sebagai bentuk yang nyata dan berwujud (asli) yang artinya bukan plagiat merupakan syarat yang harus dipenuhi dalam perlindungan hukum hak cipta. Konsep dasar lahirnya hak cipta akan memberikan perlindungan terhadap karya cipta yang memiliki ciri khas dan menunjukan keaslian atas dasar kreatifitas atau kemampuan seseorang yang bersifat pribadi. Adapun penggunaan batasan-batasan hak cipta terhadap

${ }^{4}$ Rooseno Harjowidigdo, 1994, Mengenal Hak Cipta Indonesia, Pustaka Sinar Harapan, Jakarta, h. 27. 
penggunaan, pengambilan pengubahan maupun penggadaan baik sebagian atau seluruhnya yang tidak termasuk dalam perbuatan yang melanggar Hak Cipta bila sumbernya disebutkan secara lengkap untuk kepentingan pendidikan, penelitian, keamanan serta penyelenggaraan pemerintahan. Locke menyatakan bahwa atas milik pribadi bermula dari kerja manusia, dan dengan kerja inilah manusia memperbaiki dunia ini demi kehidupan yang layak tidak hanya untuk dirinya melainkan juga untuk orang lain. Hak milik manusia terhadap benda yang dihasilkannya telah ada sejak manusia lahir. Benda tidak hanya berwujud saja, namun juga benda abstrak yang merupakan hasil dari intelektualitas manusia. ${ }^{5}$ Hak cipta di Indonesia mengandung dua jenis hak yaitu hak moral (moral rights) dan hak ekonomi (economc right). Hak moral tersebut merupakan hak khusus dan kekal yang dimiliki si pencipta atas ciptaannya, hak itu tidak dapat dipisahkan dari si pencipta. Kepemilikan hak cipta bisa saja dipindahkan kepada pihak lain tetapi hak moralnya tidak dapat dipisahkan dari si pencipta. ${ }^{6}$ Hak Moral melindungi kepentingan pribadi atau reputasi pencipta. Sifat pribadi menunjukan ciri khas yang berkenaan dengan nama baik, kemampuan dan intergaritas yang hanya dimiliki oleh pencipta atau penemu dan kekal artinya melekat pada pencipta selama hidup bahkan setelah meninggal dunia. ${ }^{7}$ Pengaturan yang berlaku bagi perlindungan hak cipta di Indonesia adalah Undang-Undang Nomor 28 Tahun 2014 tentang hak cipta. Undang-Undang ini bertujuan

5 John Locke, 2004, The Second Treatise of Government, Barnes and Noble Publising, New York, h. 17-19.

${ }^{6}$ Muhammad Djumhana dan R. Djubaedillah, 2003, Hak Milik Intelektual PT. Citra Aditya Bakti, Bandung, h. 74.

7 Ni Putu Utami Indah Damayanti dan A.A. Sri Indrawati dan A.A. Sagung Wiratni Damardi, 2018, Karya Cipta Electronic Book (E-Book) : Studi Normatif Perlindungan Hak Ekonomi Pencipta, Jurnal Kertha Semaya, Fakultas Hukum Universitas Udayana, Vol. 6 , No. 3, h. 12, URL: https://ojs.unud.ac.id/index.php/kerthasemaya/article/view/41403, diakses pada 17 Maret 2019 pukul 19:25. 
untuk memberikan perlindungan bagi si pencipta terhadap karya yang telah dibuatnya berdasarkan kreativitasnya sendiri. Hal ini dapat dilihat dari pasal-pasal di dalamnya yang lebih memberi kepastian hukum bagi pencipta. Sebagaimana tercantum dalam Pasal 9 ayat 1 Undang-Undang Nomor 28 Tahun 2014 bahwa Pencipta atau pemegang hak cipta memiliki hak ekonomi untuk melakukan penerbitan ciptaan, penggandaan ciptaan, penerjemahan ciptaan, pengadaptasian ciptaan, pendistribusian ciptaan, pertunjukan ciptaan, pengumuman ciptaan, komunikasi ciptaan dan penyewaan ciptaan. Hak cipta sebagai hak ekonomi dilihat dari penerapan hak eksklusif bertujuan agar pemegang hak cipta dapat melakukan kegiatan memperbanyak hasil ciptaannya dan selanjutnya diperjualbelikan di pasaran, maka dari hasil penjualan tersebut si pencipta dapat memperoleh keuntungan materi. Hak ekonomi suatu ciptaan tetap berada di tangan pencipta atau pemegang hak cipta, selama seluruh hak ekonomi tersebut tidak dialihkan kepada penerima pengalihan hak atas ciptaan. Hak ekonomi yang dialihkan pencipta atau atau pemegang hak cipta untuk seluruhnya atau sebagian tidak dapat dialihkan untuk kedua kalinya oleh pencipta atau pemegang hak cipta yang sama. ${ }^{8}$ Sementara itu, bagi setiap orang yang tanpa izin pencipta atau pemegang hak cipta melaksanakan hak ekonomi dari suatu ciptaan maka dilarang melakukan penggandaan atau penggunaan ciptaan tersebut secara komersial. Hal ini diatur dalam Pasal 9 ayat 3 Undang-Undang Nomor 28 Tahun 2014 tentang Hak Cipta menyatakan bahwa setiap orang yang tanpa izin pencipta atau pemegang hak cipta dilarang melakukan penggandaan dan atau penggunaan secara komersial ciptaan. Dengan banyaknya 4.

8 Tim Visi Yustisia, 2015, Panduan Resmi Hak Cipta, Visimedia, Jakarta, h. 
pelanggaran hak cipta dan besarnya kerugian yang telah diderita oleh pencipta maupun pemerintah, dapat diketahui ada sesuatu yang tidak berjalan dalam sistem perlindungan hak cipta di Indonesia. Tidak berjalannya sistem hukum atau dalam hal ini penegakkan aturan mengenai hak cipta adalah akibat dari kompleksnya permasalahan yang ada di dalam masyarakat. ${ }^{9}$ Bentuk perbuatan pelanggaran hak cipta sebagaimana dimaksud pasal 9 ayat 3 Undang-Undang Nomor 28 Tahun 2014 tentang Hak Cipta apabila dilanggar maka dikenakan Pasal 113 Undang-Undang Nomor 28 Tahun 2014 tentang Hak Cipta yang berisikan denda ataupun sanksi.

\subsubsection{Bentuk Pertanggungjawaban Pengelola Pasar terkait Penjualan Hasil Barang Pelanggaran Hak Cipta}

Pertanggungjawaban merupakan salah satu bentuk penyelesaian antara kedua belah pihak yang timbul akibat terjadinya pelanggaran yang dilakukan oleh salah satu pihak. Salah satu contoh bentuk pertanggungjawaban adalah terkait permasalahan pengelola pasar yang masih melakukan aktivitas perdagangan dengan menjual hasil barang pelanggaran hak cipta. Pengelola pasar memberikan tempat dan menyediakan fasilitas untuk menjual barang-barang pelanggaran hak cipta dengan cara penggandaan atau memperbanyak barang sehingga pengelola pasar mendapatkan keuntungan yang lebih banyak. Hal tersebut diatur dalam Undang-Undang Nomor 28 Tahun 2014 yaitu pasal 10 yang melarang pengelola tempat perdagangan membiarkan penjualan barang hasil pelanggaran hak cipta dan/atau hak yang terkait di

9 Dede Sukma Aristya dan Nyoman Mas Ariyani, 2016, Perlindungan Hukum Terhadap Produsen Atas Penyebaran DVD Bajakan di Indonesia (Ditinjau Dari Undang-Undang Nomor 28 Tahun 2014 Tentang Hak Cipta), Jurnal Kertha Semaya, Fakultas Hukum Universitas Udayana, Vol. 4, No. 4, h.4, URL: https://ojs.unud.ac.id/index.php/kerthasemaya/article/view/21898, diakses pada 17 Maret 2019 pukul 19:35. 
tempat perdagangan yang dikelolanya dimaksudkan agar dapat mewujudkan nilai keadilan terutama bagi pencipta sebagai upaya menjamin diperolehnya hak ekonomi si pencipta.

Ketentuan pasal 10 Undang-Undang Nomor 28 Tahun 2014 tentang Hak Cipta secara spesifik memberikan tanggung jawab kepada pengelola pasar sebagai pengelola tempat perdagangan untuk mengawasi tindakan penjualan, penggandaan, maupun transaksi produk yang dihasilkan dari pelanggaran hak cipta. Para pengelola pasar yang lalai akan dipidana dengan hukuman denda hingga Rp 100.000.000.- (seratus juta rupiah). Dalam hal ini ketentuan pada pasar 10 Undang-Undang Nomor 28 Tahun 2014 telah lebih memberikan perlindungan terhadap pencipta atau pemegang hak cipta dibandingkan dengan Undang-Undang sebelumnya karena dapat dikatakan lebih memberikan rasa keadilan bagi si pencipta atas berbagi tindakan pelanggaran hak ekonomi suatu ciptaan serta dimaksudkan agar pengelola pasar lebih menghargai hasil karya pencipta. Dengan demikian pertanggungjawaban atas peredaran karya cipta illegal tidak hanya bertumpu pada pihak pengganda maupun penjual saja.

Subekti mengatakan bahwa hukum bertujuan untuk melayani tujuan negara dengan mengadakan keadilan dan ketertiban. Ditegaskan bahwa keadilan bisa digambarkan sebagai sebuah keadaan yang membawa ketentraman dalam hati setiap orang, dan jika terusik atau dilanggar maka tidak ada kedamaian. Demikian juga dengan para pencipta yang akan terusik apabila hak-haknya dilanggar. Keadilan tersebut juga memiliki kandungan berupa unsur "penghargaan, penilaian, pertimbangan dan karena ini lazim disimbolkan dengan neraca keadilan yang dapat dikatakan bahwa keadilan tersebut menuntun kepada penerimaan bagian yang sama. Kaitannya antara konteks hak cipta dengan keadilan adalah 
mengenai perolehan hak ekonomi pencipta. Keadilan bisa tercapai apabila sama-sama menguntungkan semua yang terlibat dalam proses mendapatkan hak ekonomi dari suatu karya cipta dan pengelola pasar yang memberikan tempat perdagangan merupakan secara tidak langsung menjadi salah satu pihak yang terlibat di dalamnya. Dalam keterlibatannya, pengelola pasar dapat melakukan pelanggaran hak cipta ketika ia mengetahui dan dengan sengaja membiarkan terjadinya kegiatan penjualan dari hasil barang pelanggaran hak cipta. Tetapi jika pengelola pasar tidak mengetahui adanya penjualan dari barang pelanggaran hak cipta tersebut maka ia tidak mempunyai tanggung jawab atas pelanggaran hak cipta tersebut. Untuk itu perlu adanya penanganan khusus dari pemerintah untuk lebih mengefektifkan dalam menemukan pelaku kejahatan hak cipta. Peraturan perundang-undangan mengenai hak cipta telah beberapa kali mengalami perubahan namum hingga kini para pelaku pelanggaran terhadap karya cipta masih berlangsung dan tidak menimbulkan efek jera bagi pelakunya sehingga pemegang karya cipta dan juga masyarakat sangat dirugikan. Kerugian ini menimbulkan hilangnya hak ekonomi bagi si pencipta dan ketidakpuasan masyarakat dengan adanya karya cipta yang tidak original sehingga kualitas karya cipta tersebut rendah. Peraturan tersebut pun tidak cukup dalam menangani pengelola pasar "nakal" yang masih saja tidak menggubris peraturan tersebut, untuk itu perlu adanya sosialisasi terhadap ketentuan baru dalam Undang-Undang Nomor 28 Tahun 2014 kepada pusat-pusat perdagangan untuk menyadarkan mereka akan tanggung jawabnya. Meskipun adanya sosialisasi belum memaksimalkan dalam pemberantasan bagi pelaku pelanggaran hak cipta, tetapi setidaknya dapat mengurangi terjadinya permasalahan dalam penjualan barang yang melanggar 
hak cipta (illegal), sehingga pemberantasan pelaku tersebut pelanpelan dapat dioptimalkan.

Di dalam kasus menjual hasil barang pelanggaran hak cipta khususnya penggandaan atau memperbanyak barang, jika para penjual dipertanyakan mengapa mereka melakukan hal tersebut alasannya pada umumnya adalah alasan ekonomi. ${ }^{10}$ Alasan ekonomi memang sangat sulit dalam penyelasaian kasus ini, dikarenakan tidak semua masyarakat memperoleh pendapatan yang cukup sehingga mereka sudi melakukan perbuatan yang merugikan mereka sendiri. Tetapi pada dasarnya alasan mereka ini tidak dapat dibenarkan menurut hukum, karena selain bukan alasan pembenar untuk melakukan suatu tindak pidana, alasan tersebut pun tidak dapat dibenarkan sepenuhnya diterima oleh akal sehat manusia. Apalagi di jaman modern ini, seluruh masyarakat dapat dengan bebas menuangkan kreativitasnya dalam menciptakan karya seni, sehingga karya seni patut di apresiasikan.

\section{PENUTUP}

\subsection{Kesimpulan}

Berdasarkan pembahasan yang telah disampaikan diatas, maka dapat ditarik kesimpulan sebagai berikut :

1. Pengaturan hak cipta dan Bentuk pelanggaran hak cipta diatur dalam Undang-Undang Nomor 28 Tahun 2014 tentang Hak Cipta, perbuatan yang dikategorikan sebagai pelanggaran adalah perbuatan memperbanyak atau menggandakan, mengumumkan tanpa ijin pencipta dengan tujuan untuk komersial.

10 Aan Priyatna, 2016, Penegakan Hukum Terhadap Pelanggaran Hak Cipta Dalam Pembuatan E-Book, E-Jurnal Program Studi Kenotariatan Fakultas Hukum Universitas Diponegoro, Semarang, Vol. 9, No. 1, h.15. URL: https://ejournal.undip.ac.id/index.php/notarius/article/viewFile/11954/9140 diakses pada 17 Maret 2019 pukul 20:16. 
2. Pengelola pasar tidak dapat dipertanggung jawabkan atas perbuatannya membiarkan penjualan atas barang-barang hasil pelanggaran hak cipta dengan syarat pengelola pasar dapat membuktikan bahwa dirinya tidak mengetahui bahwa barang yang dijual tersebut merupakan hasil pelanggaran hak cipta.

\subsection{Saran}

Adapun saran yang dapat diberikan berdasarkan permasalahan diatas :

1. Pencipta hendaknya mendaftarkan hasil ciptaannya agar dapat dijadikan sebagai pembuktian apabila terjadi sengketa di kemudian hari.

2. Pemerintah sebagai pembentuk produk hukum hendaknya perlu memperjelas kembali bentuk pertanggungjawaban yang seharusnya diberikan oleh pihak yang melanggar hak cipta. 


\section{DAFTAR PUSTAKA}

\section{Buku}

Djumhana, Muhammad dan R. Djubaedillah, 2003, Hak Milik Intelektual, PT. Citra Aditya Bakti, Bandung.

Faisal, 2015, Pemaknaan Hukum Progresif, Thafamedia Press, Semarang.

Harjowidigdo, Rooseno, 1994, Mengenal Hak Cipta Indonesia, Pustaka Sinar Harapan, Jakarta.

Locke, John, 2004, The Second Treatise of Government, Barnes and Noble Publising, New York.

Susanti, Diyah Octorina dan Effendi, A'an, 2010, Penelitian Hukum, Sinar Grafika, Surabaya.

Tim Visi Yustisia, 2015, Panduan Resmi Hak Cipta, Visimedia, Jakarta.

\section{Jurnal dan Karya Ilmiah}

Priyatna, Aan, 2016, "Penegakan Hukum Terhadap Pelanggaran Hak Cipta Dalam Pembuatan E-Book", E-Jurnal Program Studi Kenotariatan Fakultas Hukum Universitas Diponegoro, Semarang, Vol. 9, No. 1, h. 15. URL: https:/ / journal.undip.ac.id/index.php/notarius/article/view File/11954/9140 diakses pada 17 Maret 2019 pukul 20:16.

Damayanti, Indah dan Sri Indrawati, Anak Agung dan Wiratni, Anak Agung, 2018, "Karya Cipta Electronic Book (E-Book) : Studi Normatif Perlindungan Hak Ekonomi Pencipta", Jurnal Kertha Semaya, Fakultas Hukum Universitas Udayana, Vol. 6, No.3,h.12,URL:

https://ojs.unud.ac.id/index.php/kerthasemaya/article/view 141403, diakses pada 17 Maret 2019 pukul 19:25.

Sukma, Dede dan Ariyani, Nyoman, 2016, Perlindungan Hukum Terhadap Produsen Atas Penyebaran DVD Bajakan di Indonesia (Ditinjau Dari Undang-Undang Nomor 28 Tahun 2014 Tentang Hak Cipta), Jurnal Kertha Semaya, Fakultas Hukum Universitas Udayana, Vol. 4, No. 4, h. 4, URL: https://ojs.unud.ac.id/index.php/kerthasemaya/article/view L21898, diakses pada 17 Maret 2019 pukul 19:35.

\section{Peraturan Perundang-undangan}

Undang-Undang Nomor 28 Tahun 2014 tentang Hak Cipta. 